\title{
$\beta$-Phenylethylamine 誘導体の中枢作用（8）
}

—Metaraminol 脳内投与によるマウス自発運動量増加作用について—

\author{
東海林 徹, 桜田忍, 木皿 憲佐 \\ 東北薬科大学薬品作用学教室* \\ (昭和51年 4 月 30 日)
}

\begin{abstract}
要約 : Metaraminol (MA) をマウス脳内に直接投与すると二相性作用がみられるが，今回は 第一相目の自発運動量六進作用について検討を加えた。 その結果, 1) MA 40,80 および 160 $\mu \mathrm{g}$ をマウス脳内に投与すると, 投与 30 分後汃ら自発運動量は増加し, 90 分後に saline 群まで 回復した. 2) Isocarboxazide (Iso) $10 \mathrm{mg} / \mathrm{kg}$ を MA 投与 1 時間前に処理して自発運動量を 測定すると， MA 40 および $80 \mu \mathrm{g}$ 投与で, saline 処理群と比較して自発運動量の有意な増 加が認められた。 Iso-MA で引き起てされた自発運動量の増加は MA 単独群と比較しても有 意であった。 さらに Iso $30 \mathrm{mg} / \mathrm{kg}$ 前処理群において自発運動量は Iso $10 \mathrm{mg} / \mathrm{kg}$ 前処理後に MA を投与した群と比較しても有意に増加した. 3) $\alpha$-Methyl-p-tyrosine $(\alpha$-MT) $125 \mathrm{mg} / \mathrm{kg}$ を 3 時間毎に 2 回処理した場合の MA の作用を検討すると, $\alpha$-MT-MA 投与群では $\alpha$-MTsaline 群と比較し自発運動量の有意な増加がみられたが, tween-saline 群と比較すると減少し たままであった．4） $\alpha$-MT 投与後 L-DOPA $400 \mathrm{mg} / \mathrm{kg}$ を処理し，MA を投与すると用いた いずれの用量でも tween-tween-MA 投与群の自発運動量まで回復することが認められた．5) diethyl dithio carbamate (DDC) $700 \mathrm{mg} / \mathrm{kg}$ 処理後 MA を投与すると DDG-saline 群と比 較して自発運動量の有意な増加が認められた。しかし，DDG-MA 群と tween-MA 群との間 の有意な差は認められなかった，6）MA の自発運動量六進作用は haloperidol によって抑制 された。 以上の結果より，MA の有する自発運動量圥進作用は脳内 catecholamine $(\mathrm{CA})$ を 介して発揮され, noradrenaline (NA) より dopamine (DA) が重要な役割を果している可能 性が示唆される。
\end{abstract}

\section{緒言}

著者ら ${ }^{1,2)}$ は先にマウス脳内に MA を投与すると， マウス自発運動量は投与90分後位までは増加する（第 一相目）が, 反対に投与90分後以降減少する（第二相目）という MA の二相性作用について報告した. さらに この MA の第一相目の自発運動量六進作用は 6-hydroxydopamine および reserpine を用いた実験から直接中枢 CA 受容体を興奮させる可能性と中枢 CA を介する間接作用の可能性を示唆したが依然として判然としない.

そてで今回はての点を明確にするため, 脳内 CA 亿影響をおよぽす種々の薬物を前処理して MA 投与時の 自発運動量を光束法を用いて測定した。 その結果, MA の第一相目の自発運動量穴進作用は Iso によって増強 され，DDC そよっては影響を受けず， $\alpha$-MT および haloperidol によって抑制され，さらに $\alpha$-MT で抑制さ れた MA の自発運動量は L-DOPA 処理で MA 単独処理群の運動量まで回復するという結果を得た. その結 果を以下に報告する.

\section{実験材料および方法}

\section{1. 実験動物および実験材料}

実験には体重 20〜26g の ddYS 系雄マウスを用いた。 また使用した薬物は次の通りであるＬ-1-(m-hydroxyphenyl)-2-amino-1-propanol hydrogen-bitartrate (metaraminol, 日本メルク万有) (MA), $\alpha$-methyl-ptyrosine (Sigma) ( $\alpha$-MT), L-3, 4-dihydroxy phenylalanine (協和発酵) (L-DOPA), diethyl dithio carbamate

* 焉983 仙台市小松島4-4-1 
$\mathrm{Na}$ (和光純薬) (DDC), isocarboxazide（武田薬品）(Iso）および haloperidol（大日本製薬）である．MA は生 理食塩水 (saline) そ溶解し, $0.1 \mathrm{~N} \mathrm{NaOH}$ で pH 6.0 6.4 そなるように調整し, $0.02 \mathrm{ml} / \mathrm{mouse}$ の割合で Brittain ら² の方法に従って脳内投与した. また他の薬物は $0.5 \%$ tween に懸濁し，マウス体重 $20 \mathrm{~g}$ あたり $0.2 \mathrm{ml}$ の割合で i.p. 投与した. なお MA の投与量は bitartrate としての用量である.

\section{2. 自発運動量測定法}

マウス自発運動量は光束法 ${ }^{4,5)}$ で測定した. すなわち, 防音暗箱 $(20 \times 20 \times 20 \mathrm{~cm})$ 中にマウス 2 匹を入れ底 上 $2 \mathrm{~cm}$ の高さからでる光束をマウスが横切るとき, その運動量がカウントされる装置を用いた. なお, マウス を装置にならすため薬物投与前15分間装置に入れてから，自発運動量測定を行なった。

\section{実 験 成 績}

\section{Isocarboxazide 前処理マウスの自発運動量におよぼす metaraminol の影響}

著者らは MA 投与後90分間の累計自発運動量が saline 投与群に比較して有意に増加するてとを前報で示し たが，投与120分後までの経時変化について検討を加えた結果は Fig. 1 に示す通りである.
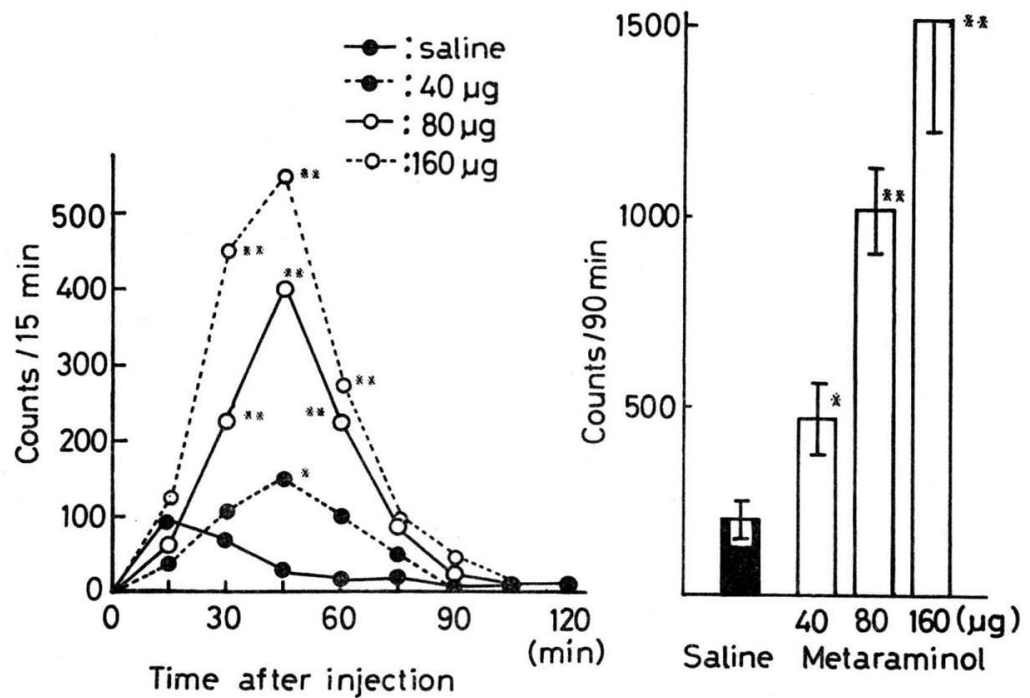

Fig. 1. Effects of metaraminol given i.c. on spontaneous motor activity measured by photocell counters method in mice. Results are the mean \pm S.E. of 12 experiments.

$* \mathrm{p}<0.05$ when compared with saline treated group. $* * \mathrm{p}<0.01$ when compared with saline treated group.

すなわち, MA 40 160 $\mu \mathrm{g}$ 投与の結果, 投与30分後から60分後まで対照群と比較して自発運動量の有意な 増加が認められ，投与75分後には対照群との差が認められないまでに回復した。

Iso を前処理後, MA のマウス自発運動量におよぼす影響について検討を加えた結果は Fig. 2 に示す通り である.

すなわち Iso $10 \mathrm{mg} / \mathrm{kg}$ i.p. 処理 1 時間後に saline を i.c. 投与した対照群では投与15分後に自発運動量の ピークがみられ，78.9カウントを示し，90分間の累計カウント数は 259.8土73.3 であった. それに対し，Iso 処 理後 MA を投与すると, $20 \mu \mathrm{g}$ 投与群での経時変化は対照群とほぼ同じであり, 90分間の累計カウント数も対 照群に比べ有意な変化は認められなかった。 しかし, $40 \mu \mathrm{g}$ 投与群では投与60分後より自発運動量の有意な増加 が認められ，90分間の累計カウント数も対照群の值と比べ有意な増加か認められた.さらに $80 \mu \mathrm{g}$ 投与群では, MA 投与45分後以降対照群と比較して有意な運動量の増加がみられ，90分後にそのピークがみられ，90分間の 累計カウント数は対照群と比べ有意な増加が認められた. なお Iso 前処理後に MA $80 \mu \mathrm{g}$ 投与したときの90 

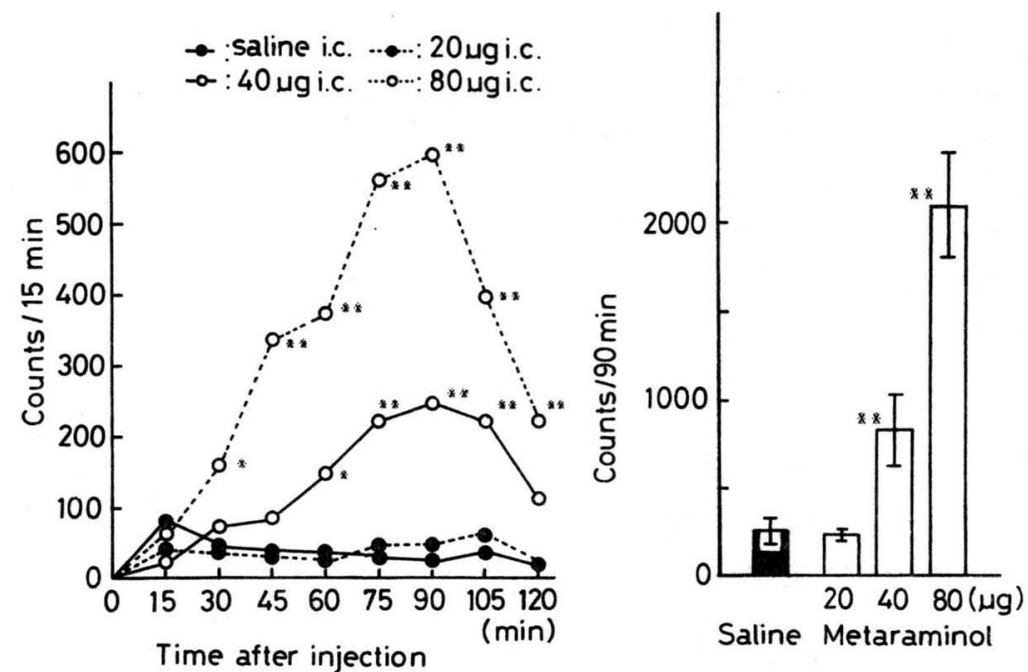

Fig. 2. Effects of metaraminol on spontaneous motor activity measured by photo-cell counters method in isocarboxazide pretreated mice. Isocarboxazide $(10 \mathrm{mg} / \mathrm{kg}$ i.p.) was administered $1 \mathrm{hr}$ before i.c. administration of metaraminol. Results are the mean \pm S.E. of 6 experiments. $* \mathrm{p}<0.05$ when compared with saline treated group. ** $\mathrm{p}<0.01$ when compared with saline treated group.

分間の累計カウント数は MA $80 \mu \mathrm{g}$ 単独投与群の值と比べて有意に増加していた.

一方, Iso の用量を増加し， $30 \mathrm{mg} / \mathrm{kg}$ を処理後に MA を投与したときの運動量を測定した結果は Fig. 3 に示す通りである.

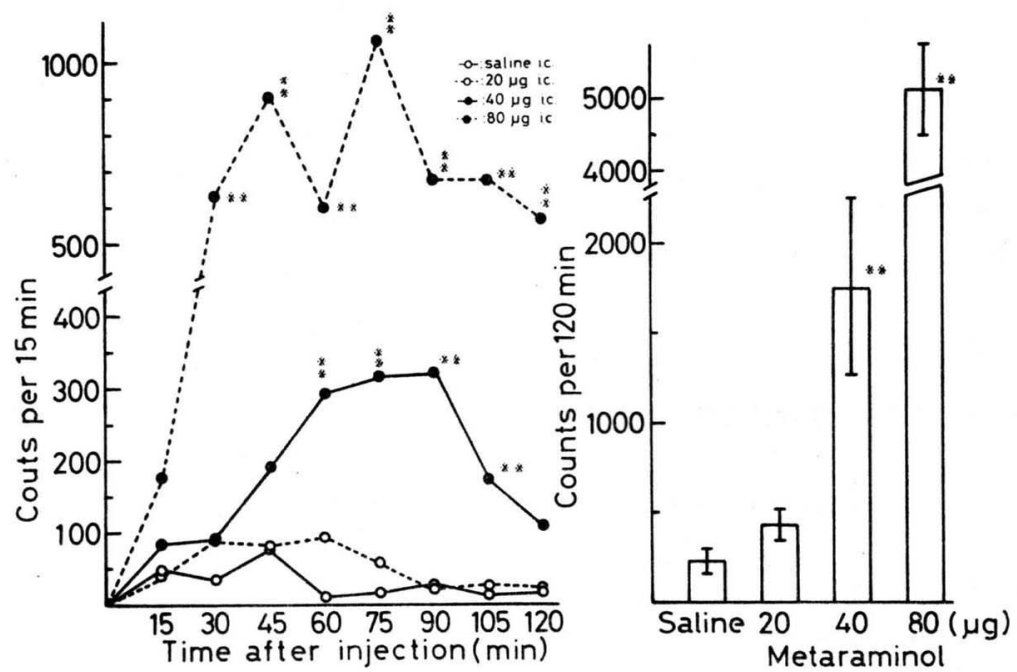

Fig. 3. Effects of metaraminol on spontaneous motor activity measured by photo-cell counters method in isocarboxazide pretreated mice. Isocarboxazide ( $30 \mathrm{mg} / \mathrm{kg}$ i.p.) was administered $1 \mathrm{hr}$ before i.c. administration of metaraminol. Results are the mean \pm S.E. of 6 experiments. $* * \mathrm{p}<0.01$ when compared with saline treated group.

すなわち, Iso $30 \mathrm{mg} / \mathrm{kg}$ i.p. 投与 1 時間後, MA を投与すると自発運動量の増加がみられ，とくに40および $80 \mu \mathrm{g}$ 投与群に於ては MA 単独投与群および Iso $10 \mathrm{mg} / \mathrm{kg}$ 前処理後 MA 投与した群の自発運動量と比較して 有意な増加が認められた。このように MA の自発運動量増加作用は Iso 前処理により増強かつ持続することが 
認められた。

\section{2. $\alpha$-Methyl-p-tyrosine 処理後 metaraminol を投与したときのマウス自発運動量}

$\alpha$-MT は tyrosine hydroxylase を阻害し内因性の CA を枯渇させることは周知の事実である6,7). そてで 今回の実験では MA の自発運動量増加作用は内因性の CA を介して発揮されるか否かを検討するため, $\alpha-\mathrm{MT}$ を前処理して脳内 CA を枯渴させた場合に MA の自発運動量増加作用が発現するか否かを検討した。 $\alpha$-MT の 処理は $125 \mathrm{mg} / \mathrm{kg}$ を 3 時間毎に 2 回 i.p. 投与し, 最終投与 3 時間後に MA を投与した. その結果は, Fig. 4 に示す通りである。

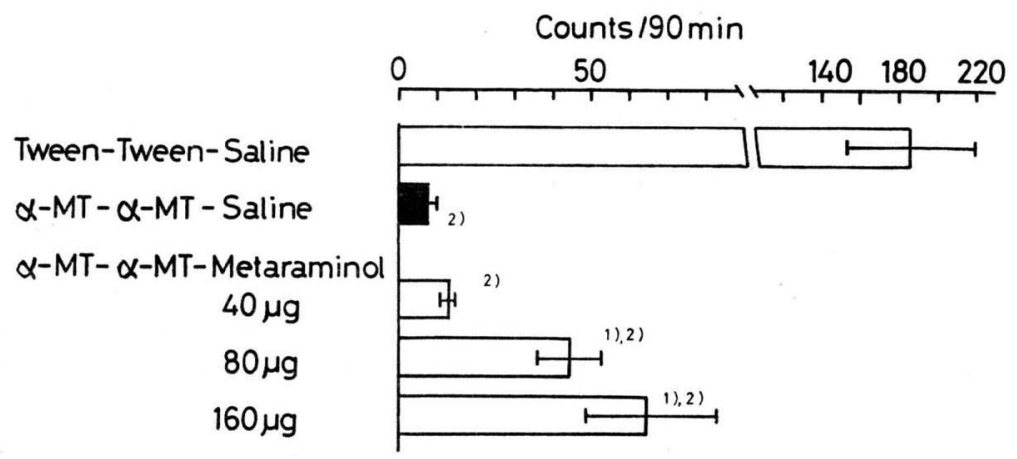

Fig. 4. Effects of metaraminol on spontaneous motor activity measured by photo-cell counters method in $\alpha$-methyl-p-tyrosine pretreated mice. $\alpha$-Methyl-p-tyrosine $(125 \mathrm{mg} / \mathrm{kg}$ i.p.) was administered twice at 6 and $3 \mathrm{hr}$ before metaraminol. Results are the mean \pm S.E. of $6 \sim 12$ experiments. 1) $\mathrm{p}<0.01$ when compared with $\alpha$-methyl-p-tyrosine + saline treated group. 2) $\mathrm{p}<0.01$ when compared with tween + saline treated group.

すなわち, tween を 2 回 i.p. 投与し saline を投与した群 (tween-saline 群) において, 90分間の累計カウ ント数は 186.9土33.9 であった. それに対し， $\alpha$-MT 処理後 saline を投与した対照群では鎮静状態になるとと が認められ, 90分間の累計カウント数は $7.2 \pm 2.3$ と tween-saline 群に比べ運動量の著明な減少が認められた.

一方, $\alpha-\mathrm{MT}$ 処理後 MA 40, 80 および $160 \mu \mathrm{g}$ 投与した群における90分間の累計カウント数はそれぞれ 13.4 $\pm 1.8,45.2 \pm 8.0$ および $64.9 \pm 17.3$ と対照群と比較して MA の用量に従ってカウント数が増加し, MA 80 および $160 \mu \mathrm{g}$ 投与群のカウント数は刘照群と比較し有意な増加であった. しかし $\alpha$-MT-MA 群の運動量は, tween-MA 群と比べて著明に減少しており, さらに, tween-saline 群と比べても著明に減少するてとが認められ た. このように MA の自発運動量増加作用は $\alpha$ - MT 前処理によってほとんど消失するととが認められた.

\section{Metaraminol の運動量増加作用におよぼす $\alpha$-methyl-p-tyrosine および L-DOPA 併用の影響}

MA の自発運動量圥進作用は $\alpha-\mathrm{MT}$ 処理によって消失することを認めたので， $\alpha$-MT 処理したマウスに L-DOPA を投与し, 脳内 CA を再び増加させたときの MA のマウス自発運動量におよぼす影響を検討した。 $\alpha$-MT 処理は Fig. 4 亿従い, $\alpha$-MT 最終処理 2.5 時間後に L-DOPA を i.p. 投与し, 0.5 時間後に MA を投 与した. その結果は Fig. 5 亿示す通りである.

すなわち， $\alpha$-MT および tween を前処理し MA $80 \mu \mathrm{g}$ 投与した群 $(\alpha-\mathrm{MT}+$ tween + MA $80 \mu \mathrm{g}$ 群) 亿 おいては, その自発運動量は $\alpha$-MT-MA $80 \mu \mathrm{g}$ 群と同程度に減少するととが想められ, その 90 分間の累計カウ ント数は $45.3 \pm 9.3$ であった. また， $\alpha$-MT および L-DOPA 200 および $400 \mathrm{mg} / \mathrm{kg}$ 処理し saline を投与し た群（それぞれ $\alpha$-MT+L-DOPA $200 \mathrm{mg} / \mathrm{kg}+$ saline 群および $\alpha$-MT+L-DOPA $400 \mathrm{mg} / \mathrm{kg}+$ saline 群) でも $\alpha$-MT+tween+MA $80 \mu \mathrm{g}$ 群との間の有意な差を認めるととは出来なかった.

一方, $\alpha$-MT+L-DOPA $200 \mathrm{mg} / \mathrm{kg}+\mathrm{MA} 80 \mu \mathrm{g}$ 投与群では MA 投与30分後から自発運動量の増加がう れ60分後にピークに達し, 90分間の累計カウント数は $\alpha$-MT+tween+MA $80 \mu \mathrm{g}$ 群と比較してあるいは $\alpha-\mathrm{MT}$ +L-DOPA $200 \mathrm{mg} / \mathrm{kg}+$ saline 群と比較して有意な增加が認められたが, tween+tween+MA $80 \mu \mathrm{g}$ 投与群ま 


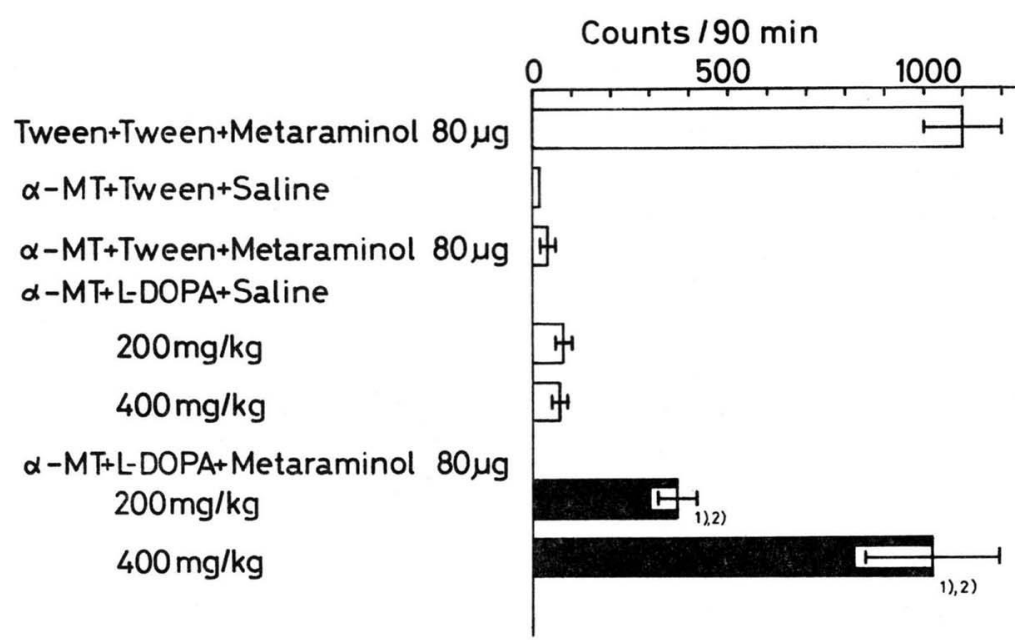

Fig. 5. Effects of metaraminol on spontaneous motor activity measured by photo-cell counters method in $\alpha$-methyl-p-tyrosine+L-DOPA pretreated mice. $\alpha$-Methyl-p-tyrosine (125 $\mathrm{mg} / \mathrm{kg}$ i.p.) was administered twice at 6 and $3 \mathrm{hr}$ before metaraminol (80 $\mu \mathrm{g}$ i.c.) and L-DOPA was administered $30 \mathrm{~min}$ before metaraminol. Results are the mean士 S.E. of 6 experiments. 1) $\mathrm{p}<0.01$ when compared with $\alpha$-methyl-p-tyrosine + tween + metaraminol (80 $\mu$ g i.c.) treated group. 2) $\mathrm{p}<0.01$ when compared with $\alpha$-methylp-tyrosine + L-DOPA + saline treated group.

での回復は認められなかった。しかし， $\alpha$-MT+L-DOPA $400 \mathrm{mg} / \mathrm{kg}+\mathrm{MA} 80 \mu \mathrm{g}$ 投与群の自発運動量は MA 投与15分後から $\alpha$-MT+tween+MA $80 \mu \mathrm{g}$ 群と比べ有意な増加を示し，45分後にピークに達し90分間の累計カ ウント数は tween+tween+MA $80 \mu \mathrm{g}$ 群までのカウント数に回復することが認められた.

Fig. 3 に示した通り， $\alpha$-MT で減少した MA $80 \mu \mathrm{g}$ 投与によるマウス自発運動量は L-DOPA $400 \mathrm{mg} / \mathrm{kg}$ 投与によって回復することが認められたので， $\alpha$-MT+L-DOPA $400 \mathrm{mg} / \mathrm{kg}$ 投与し，MA 40 および $160 \mu \mathrm{g}$ を

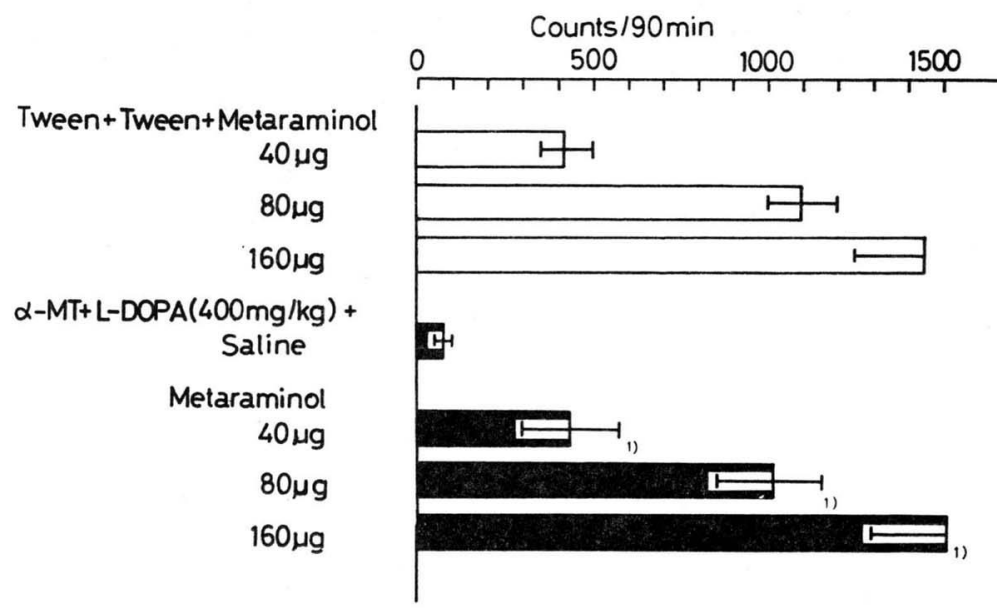

Fig. 6. Effects of metaraminol on spontaneous motor activity measured by photo-cell counters method in $\alpha$-methyl-p-tyrosine+L-DOPA pretreated mice. $\quad \alpha$-Methyl-p-tyrosine was administered as outlined in Fig. 4, L-DOPA ( $400 \mathrm{mg} / \mathrm{kg}$ i.p.) was administered $30 \mathrm{~min}$ before metaraminol. Results are the mean \pm S.E. of 6 experiments. 1) $\mathrm{p}<$ 0.01 when compared with $\alpha$-methyl-p-tyrosine+L-DOPA $(400 \mathrm{mg} / \mathrm{kg}$ i.p. $)+$ saline treated group. 
投与したときの運動量を検討した. その結果は Fig. 6 亿示す通りである.

すなわち $\alpha$-MT+L-DOPA $400 \mathrm{mg} / \mathrm{kg}+$ saline 処理群に比べ， $\alpha$-MT+L-DOPA $400 \mathrm{mg} / \mathrm{kg}+\mathrm{MA}$ 投与群 では有意な自発運動量の増加がみられた. $40 \mu \mathrm{g}$ 投与群に於ては投与30分後から自発運動量の増加がみられ, 45 分後にピークに達し 90 分間の累計カウント数は $439.5 \pm 164.0$ を示し, tween+tween+MA $40 \mu \mathrm{g}$ 投与群までの

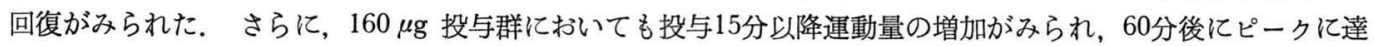
しその90分間の累計カウント数は $1521.3 \pm 236.4$ であり, $\alpha$-MT+L-DOPA $400 \mathrm{mg} / \mathrm{kg}+$ saline 群と比較して有 意な運動量の増加が認められ, tween+tween+MA $160 \mu \mathrm{g}$ 群までの回復が認められた. 以上のように $\alpha$-MT より抑制された MA の自発運動量増加作用は L-DOPA $400 \mathrm{mg} / \mathrm{kg}$ の投与により回復するととが認められた.

\section{Diethyl dithio carbamate 処理マウスの自発運動量におよぼす metaraminol の影響}

DDC を用いて内因性の NA を減少させた場合のマウス自発運動量におよばす MA の影響を検討した結果 は Fig. 7 に示す通りである。
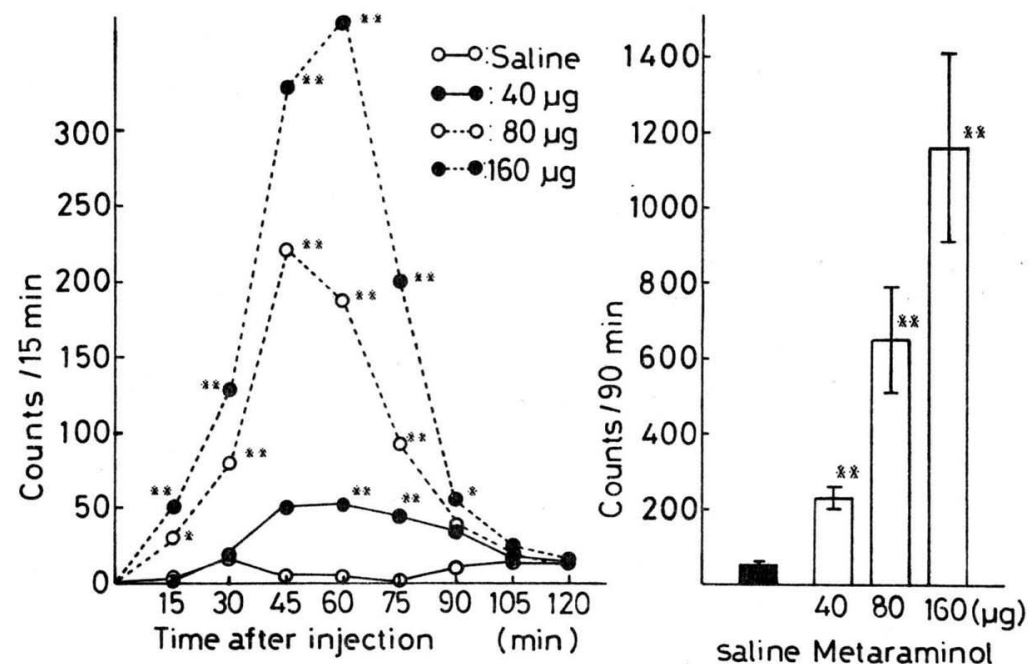

Fig. 7. Effects of metaraminol on spontaneous motor activity measured by photo-cell counters method in diethyldithiocarbamate (DDG) pretreated mice. DDC $(700 \mathrm{mg} / \mathrm{kg}$ i.p.) was administered $4 \mathrm{hr}$ before metaraminol. Results are the mean $\pm \mathrm{S}$. E. of 6 experiments. * $\mathrm{p}<0.05$ when compared with saline treated group. $* * \mathrm{p}<0.01$ when compared with saline treated group.

すなわち DDG $700 \mathrm{mg} / \mathrm{kg}$ i.p. 投与 4 時間後 saline を投与した対照群において，マウスは鎮静状態になり， ptosis さえも認められた，そして対照群の 90 分間の累計カウント数は $48.8 \pm 12.4$ と saline 単独投与群と比べ, マウス自発運動量は著明に減少した。

これに対して DDC-MA 投与群では $40 \mu \mathrm{g}$ を投与した場合45分以降90分後まで自発運動量の増加が認めら れ90分間の累計カウント数は対照群に比べ著明に増加していた. $80 \mu \mathrm{g}$ 投与群に於ては投与30分以降75分まで自 発運動量の増加が認められ，そのピークは投与45分後で90分間の累計カウント数は対照群に比べ著明に増加して いた. さらに $160 \mu \mathrm{g}$ 投与群に於ては投与 15 分以降 90 分後まで自発運動量の増加が認められ, 投与60分後に自発 運動量はピークに達し，90分間の累計カウント数は対照群に比べ著明に増加した．さらにてれらの結果を Fig. 1 に示す MA 単独投与群と比較すると MA 40, 80 および $160 \mu \mathrm{g}$ のいずれの投与群とも 90 分間の累計カウント 数には有意な差か認められなかった。

\section{Metaraminol 脳内投与時のマウス自発運動量におよぼす haloperidol の影響}

Haloperidol を MA 投与30分前に投与したときの自発運動量を検討した結果は Fig. 8 に示す通りである. 


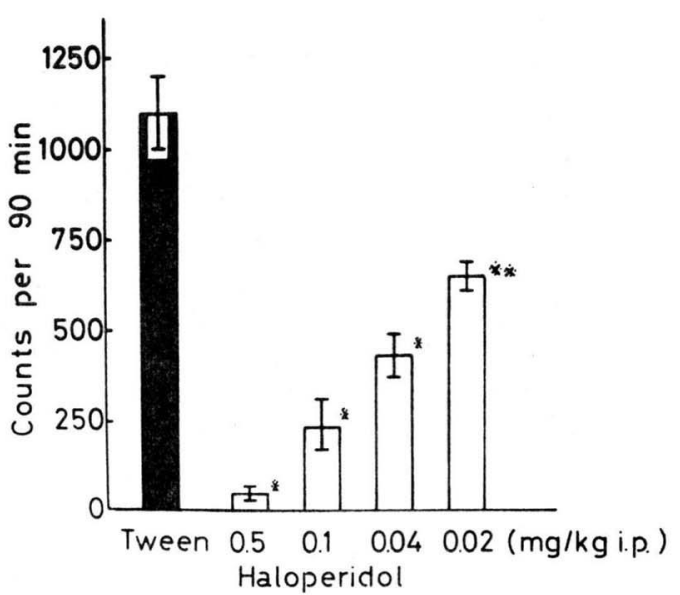

Fig. 8. Effects of metaraminol on spontaneous motor activity in haloperidol pretreated mice. Haloperidol was administered i.p. $30 \mathrm{~min}$ before metaraminol. Results are the mean \pm S.E. of 6 experiments. $* \mathrm{p}<0.01$ when compared with tween + metaraminol treated group. $* * \mathrm{p}<0.05$ when compared with tween + metaraminol treated group.

すなわち tween-MA $80 \mu \mathrm{g}$ 投与時の90分間の自発運動量に比較して haloperidol-MA $80 \mu \mathrm{g}$ 投与群の自発 運動量は著明に減少しており，MA の自発運動量増加作用は haloperidol の低用量で抑制されるてとが認められ た. そして 50\%抑制用量を求めると $0.027 \mathrm{mg} / \mathrm{kg}$ であり, この haloperidol の用量は正常マウスの自発運動量 テ対しては何ら影響をおよぱさない用量であった.

\section{考察}

先に著者ら ${ }^{2)}$ は, MA の自発運動量増加作用が, reserpine に拮抗することから, MA には直接作用を示す 可能性もあると示唆したが，との場合 MA により引き起こされる自発運動量の増加は新たに合成された CAの 利用ということも考えられるので, reserpine を用いた実験から MA の直接作用を結論付けるのは早急であると 考える．そこで今回の実験では，MA により引き起てされる自発運動量增加作用における MA と脳内 CA の 関係について更に詳細に検討を加えた.

$\alpha$ 位にメチル基を有する MA は monoamine oxidase (MAO) の基質になりにくいから，仮に MA の作 用が内因性の CA を遊離して発揮されるならば，MAO 阻害剤である Iso を前処理して MA を投与すれば， 運動量の増加が認められるはずである，ての点について Iso 前処理マウスに MA を投与したときの自発運動量 を検討すると, $40 \mu \mathrm{g}$ 投与群では投与60分後から, $80 \mu \mathrm{g}$ では45分後から control 群に比べ運動量は著明に増加 し, しかもそのピークは MA 投与90分後に認められ，90分間の累計 counts 数は MA 単独処理群のほほ 2 倍の 增加が認められた (Fig. 2). 更に Iso の用量を $30 \mathrm{mg} / \mathrm{kg}$ にすると MA の作用は更に増強され，120分間の累 計 counts 数は, Iso-40 $\mu \mathrm{g}$ および Iso-80 $\mu \mathrm{g}$ 投与群ともそれぞれ MA 単独投与群と比べて, 有意に増加する ことが認められた (Fig. 3). とのように Iso 前処理後 MA による自発運動量の増加ならびに持続は内因性の CA が MA により遊離され，その遊離された CA が Iso により代謝（MAO による）が阻害されたためと考 光られる。

次に MA の作用が内因性の CA を介して発揮されることを更に明確にするため，CA の生合成阻害羭の MA におよぼす影響を検討した。

$\alpha$-MT は脳内 CA の機能的役割を検討するための有用な薬物として広く用いられている6 . 例えば Dominic and $\mathrm{Moore}^{7)}$ は $\alpha$-MT 投与により引き起とされる運動量の減少と脳内 NA および DA の減少とを経時的に検 討し, 脳内 CA 減少と運動量の減少が一致することを証明している，また， $\alpha$-MT は中枢作用を有する種々の 薬物が直接中枢の receptor 亿作用するか不かを決定するための有用な手段となり得る．例えば d-amphetamine 
により引き起てされる自発運動量の増加は, reserpine では抑制されない8,9)が， $\alpha$-MT で抑制されることにより， $\mathrm{d}$-amphetamine の中枢作用発現には内因性の CA が必要であるといわれる ${ }^{10,111}$. また $\beta$-phenylethylamine ${ }^{122}$ お よび morphine ${ }^{13,14)}$ の運動量増加作用も $\alpha$-MT により抑制されるということから $\mathrm{GA}$ を介するものと考元ら れている. そてで $\alpha$-MT を前処理して MA の自発運動量について検討した結果, MA $160 \mu \mathrm{g}$ 投与群におい て, tween-MA 投与群の90分間の累計 counts 数に比べ $\alpha$-MT-MA 投与群のそれは約 $1 / 25$ に減少しており, MA の自発運動量増加作用は $\alpha$-MT 前処理によりほとんど抑制することが梕められた (Fig. 4). これらのとと は MA が引き起とす自発運動量増加作用は, d-amphetamine あるいは, $\beta$-phenylethylamine のそれと同様, 中枢 CA を介して発揮されるものと考えられる. しかし $\alpha$-MT 処理マウスの運動量を MA は用量に応じて増 加させている. これは， $\alpha$-MT-MA 投与群の運動量が tween-MA 投与群と比較してばかりでなく tween-saline 投与群と比較しても著明に減少しているので，MA の直接作用というよりむしろ残余の CA が MA により遊 離されたものと考えられる.

このように MA の作用は $\alpha$-MT によりほとんど抑制されたので, $\alpha$-MT で脳内 GA 枯渴後 L-DOPA を 投与して再び脳内 CA (特に DA) を増加させた時の MA の影響を次に検討した. その結果, $\alpha$-MT により抑 制された MA の運動量増加作用は，L-DOPA 処理により回復した. しかもその回復度合は L-DOPA の用量に 応じた回復で $400 \mathrm{mg} / \mathrm{kg}$ 処理でほぼ tween-MA 投与群の自発運動量まで回復した (Fig. 5, 6). てれらの結果 は, MA の自発運動量増加作用には中枢の CA が重要であることを示すものである. 事実 Banerjee ら ${ }^{15)}$ は $\alpha$-MT 処理で抑制された d-amphetamine の自発運動量は L-DOPA の投与で回復するととを見い出している.

叙上の如く，MA の第 1 相目の自発運動量増加作用は MA の直接作用よりむしろ中枢 CA を介して発揮 されると思われるが, CA のうち DA あるいはNA のいずれが関与するかは, 判然としない, そこで DA の中 枢作用を検討する上に多用されているDA- $\beta$-hydroxylase 阻害剤である DDG16) を前処理して MA 投与時の運 動量を検討した．その結果 DDC-MA 投与群の運動量は MA の用量に応じて増加した (Fig. 7). 更にとの増加 と MA 単独投与群の運動量を比較すると DDC-MA 投与群の運動量は MA の用量に応じて増加した (Fig. 7). しかしとの増加と MA 単独投与群の運動量を比較すると DDC-MA 投与群の運動量は若干減少するものの有意 な減少ではなかった（ $\mathrm{t}$ 検定 $\mathrm{p}<0.01)$. Disulfiram や DDC は脳内の DA 含量には影響をおよばさず NA のみ を選択的に枯渴させる ${ }^{17)}$. それゆ光種々薬物の DA による効果を検討する上に有用な薬物である. 例えば damphetamine の運動量増加作用は DDC により抑制されないととよりとの作用には DA か関係すると報告され ている ${ }^{18 \sim 20)}$. 著者らの実験において MA の自発運動量増加作用は DDC 亿抑制されないととより中枢 DA が重 要である可能性が示唆される.

次に MA の DA に対する作用を receptor の面から検討するため haloperidol を用いた実験を行なった。 Haloperidol は DA-receptor の阻害剤であり種々薬物の DA による効果を抑制するてとが知られている。例え ば DA- $\beta$-hydroxylase 阻害剤により抑制されなかった d-amphetamine の作用は haloperidol により抑制される ことより，ての d-amphetamine の作用には DA が重要であるということが報告されている21). 著者らの実験 において MA の自発運動量増加作用は haloperidol の低用量で抑制された (Fig. 8). この MA の作用を抑制 する haloperidol の50\%抑制用量は $0.027 \mathrm{mg} / \mathrm{kg}$ であり，ての用量は正常マウスの自発運動量に何ら影響をお よぽさない用量であった。

以上のととより MA により引き起とされる自発運動量増加作用は内因性の CA を介して発揮され，そのう ち NA よりもむしろ DA を介して発揮されると考えられる。

\section{文献}

1) 東海林 徹, 桜田 忍, 木皿憲佐：日薬理誌 71, 1 (1975)

2) 東海林 徹, 桜田 忍, 木皿憲佐: 日薬理誌 71, 11 (1975)

3) Brittain, R. T. and Handeey, S. L.: J. Physiol. 192, 805 (1967)

4) Davis, G. D.: Am. J. Physiol. 188, 619 (1957)

5) 龟山 勉, 佐々木健一, 木皿憲佐: 東北薬科大学研究年報 10, 49 (1963)

6) Moore, K. E. and Dominic, J. A.: Fedn Proc. 30, 850 (1971) 
7) Dominic, J. A. and Moore, K. E.: Archs int. Pharmacodyn. Thér. 178, 166 (1969)

8) Regh, R. H. and Stolk, J. M.: Amphetamine and Related Compounds, Edited by Costa, E. and Garattini, S., p. 385, Raven Press, New York (1970)

9) Proctor, G. D., Kirby, J., Wood, M. H., Wade, L. H. and King, P. K.: Archs int. Pharmacodyn. Thér. 212, 108 (1974)

10) Hanson, L. C. F.: Psychopharmacol. 10, 289 (1967)

11) Moore, K. E., CArr, L. A. and Dominic, J. A.: Amphetamine and Related Compounds, Edited by Costa, E. and Garattini, S., p. 371, Raven Press, New York (1970)

12) Jackson, D. M.: J. Pharm., Lond. 24, 383 (1971)

13) Villarreal, J. E., Guzman, M. and Smith, C. B.: J. Pharmacol. exp. Ther. 187, 1 (1973)

14) Kuschinsky, K. and Hornykiewicz, O.: Europ. J. Pharmacol. 26, 41 (1974)

15) Banerjee, U. and Lin, G. S.: Neuropharmacol. 12, 917 (1973)

16) Goldstern, M.: Pharmacol. Rev. 18, 77 (1966)

17) Moore, K. E.: Biochem. Pharmacol. 18, 1627 (1969)

18) Stein, L. and Weise, C. D.: Science 171, 1032 (1971)

19) Shellenberger, M. K.: Neuropharmacol. 10, 347 (1971)

20) Hollister, A. S., Breese, G. R. and Cooper, B. R.: Psychopharmacol. 36, 1 (1974)

21) Martin, D. S. and Peter G. C.: Psychopharmacol. 42, 185 (1975)

\begin{abstract}
Tohru SHOJI, Shinobu SAKURADA and Kensuke KISARA (Department of Chemical Pharmacology, Tohoku College of Pharmacy, Sendai 983, Japan). Central effects of $\beta$-phenylethylamines (Report 8)-Increase in spontaneous motor activity of intracerebrally administered metaraminol in miceFolia pharmacol. japon. 73, 15 23 (1977).

Metaraminol (MA) (40, 80 and $160 \mu \mathrm{g}$ ) was injected i.c. into mice and spontaneous motor activity (SMA) measured by photo-cell counters method was found to increase $30 \mathrm{~min}$ after the injection. Ninety min after, the SMA was restored to the saline treated control. MA (80 $\mu$ g i.c.) was also injected into isocarboxazide (Iso) pretreated mice and the SMA markdly increased as compared with the Iso + saline treated group or tween + MA treated group. When MA was injected i.c. into $\alpha$-methyl-p-tyrosine ( $\alpha$-MT) pretreated mice, the SMA significantly increased as compared with that of the $\alpha$-MT + saline treated group, but there was a decrease as compared with that of the tween + saline or tween + MA treated group. In $\alpha$-MT treated mice. L-Dopa restored the hyper-motor activity of animals treated with MA. Diethyldithiocarbamate $(700 \mathrm{mg} / \mathrm{kg}$ i.p.) had no influence, whereas haloperidol markedly blocked the hyper-motor activity induced by MA. The hyper-motor activity induced by MA in mice raised the question of a possible role of noradrenaline and dopamine in the mediation of this action.
\end{abstract}

